\title{
DEVELOPE THE CREATIVE THINKING SKILLS OF ELEMENTARY SCHOOL STUDENTS USING THE INQUIRY MODEL FOR NATURAL SCIENCES SUBJECT
}

\author{
Mufida Awalia Putri \\ Universitas Islam Negeri Syarif Hidayatullah Jakarta \\ Email: mufida.awalia@,uinjkt.ac.id
}

Naskah diterima : 23 September 2018, direvisi : 28 September 2018, disetujui : 18 Oktober 2018

\begin{abstract}
Penelitian ini bertujuan untuk memberikan gambaran bagi pendidik dan calon pendidik agar dapat memanfaatkan kegiatan penelitian dalam pengajaran ilmu pengetahuan alam, menggunakan lingkungan dan fasilitas sekolah untuk memberikan kebiasaan penelitian penemuan bagi siswa. Penelitian ini merukapan penelitian studi pustaka. Artikel ini menjelaskan keterampilan berpikir kreatif dan model inquiry. Keterampilan untuk berpikir dengan pertanyaan kritis sehingga dapat menyelesaikan masalahnya dengan kreatifitasnya. Model Inquiry adalah proses yang harus dikenali oleh guru dan memberikan banyak dorongan kepada siswa untuk menemukan masalah dan mencari solusi alternatif melalui proses ilmiah dan didukung menggunakan pemikiran kreatif dan logis. Setelah digunakan dalam pengajaran ilmu pengetahuan alam, diharapkan para pendidik dan calon pendidik dapat memiliki pemahaman bahwa kegiatan penelitian baik praktikum maupun observasi, keterampilan kreatif siswa berkembang, sehingga mereka dapat menghadapi persaingan global di abad ke-21.
\end{abstract}

Kata Kunci: ilmu pengetahuan alam, model inquiry, keterampilan berpikir kreatif

Pengutipan: Mufida Awalia Putri. (2018). Develope the Creative Thinking Skills of Elementary School Students Using the Inquiry Model for Natural Sciences Subject. JMIE: Journal of Madrasah Ibtidaiyah Education, 2(2), 2018, 232-244. jmie.v2i2.79.

Permalink/DOI: http:// dx.doi.org/ 10.32934/jmie.v2i2.79 


\section{INTRODUCTION}

Education in Indonesia is not only oriented to human intelligence, but also to the aspects of religion, self-control, personality, intelligence, noble character, and skills needed by themselves, society, nation and state. Education is a step taken by the government to prepare its citizens to be able to compete in life and maintain their lives in global competition. As referred to in Law Number 20 of 2003th concerning the National Education System Chapter I ayat 1 paragraph 1.

Education is a conscious and planned effort to realize a learning atmosphere and learning process so that students actively develop their potential to have religious spiritual strength, self-control, personality, intelligence, noble character, and skills needed by themselves, society, nation and country.

$21^{\text {st }}$ century skills have been adapted by the Ministry of Education and Culture of the Republic of Indonesia to develop new curricula for elementary schools (SD), junior high schools (SMP), high schools (SMA) and vocational high schools (SMK). Adaptation is done to achieve the concordance of the concept with the capacity of students and the competence of educators and their education personnel. This adaptation is to develop education towards Indonesia Creative in 2045.

Learning Science in Elementary Schools in the 2013 Curriculum, one of its basic competencies is to show a scientific attitude: curiosity, honesty, logical, critical, discipline, and responsibility through science. Soft skills are the key to achieving success, including leadership, decision making, conflict resolution, communication, creativity, and presentation skills.

Creative thinking is very important to elementary students. Students can develop their creativity from their games and childhood ability. From games that they do it supposed be the new knowledge and apply it in the class discussion. Creativeness can makes students to think critic and do everything by theirselves well. "Creativity is widely acknowledged to be a key 21 st century skill and included in many countries' desired college \& career ready outcomes for students.” ( P21 Headquarters: 2007).

Creativity and innovation is one of $21^{\text {st }}$ century skills. This decade makes everyone has some skills to fight and continue their life. Think Creatively indicators are: Use a wide range of idea creation techniques (such as brainstorming); Create new and worthwhile ideas (both incremental and radical concepts); and Elaborate, refine, analyze and evaluate their own ideas in order to improve and maximize creative efforts. 
Work Creatively with Others indicators are: Develop, implement and communicate new ideas to others effectively; Be open and responsive to new and diverse perspectives; incorporate group input and feedback into the work; Demonstrate originality and inventiveness in work and understand the real world limits to adopting new ideas; and View failure as an opportunity to learn; understand that creativity and innovation is a long-term, cyclical process of small successes and frequent mistakes.

iscepimplement Innovations: Act on creative ideas to make a tangible and useful contribution to the field in which the innovation will occur ( P21 Headquarters: 2007).

\section{LITERATURE REVIEW}

\section{A. Creative Thinking Skills}

Creativity is a matter of coming up with new ideas that are also useful. This brings to the important role of critical thinking in promoting creativity. First, using critical thinking to analyze a problem and identify the limitations of existing solutions. So after that know what a better solution might look like. And have a new solution, critical thinking helps us determine whether it really works. Actual creative process involves trial and error. We might have to fail a thousand times before hitting on the best solution. Good critical thinking enables us to learn from our mistakes and solve our problems more efficiently. (Lau, 2011: 216-217)

Russell \& Wyse (2013: 51) states that personal creative learning in the knowledge of students in science learning, in addition students are able to construct new things, explanations, hypotheses, arguments and procedures. Science learning has closeness through exploration carried out by students through phenomena around their environment.

Kind \& Kind (2009: 12) reveals that students should appreciate science as an activity involving creativity and imagination as much as human activity. and scientific ideas are very large in intellectual achievement. Phenoma of science is very close in developing the ability to think creatively, this is because science is based on the ability of human logic to process science in learning.

Creative people are often diligent, disciplined, and highly focused. Many have a daily work routine that they steadfastly follow. The work ethic is motivated and sustained by a passion about their work. Based on See Young (1975) and Hermann von Helmholtz (1821-1894) in (Lau, 2011: 217) a short and well-written 
book about this work process. German physiologist and physicist had a similar idea. But whatever the details, the work cycle often follows a four-step procedure:

1. Step 1 : Preparation

Start by gathering information about the problem. This might mean going to the library, searching the web, talking to people, or collecting data or other items. Keep everything that have found in a way that students can access them easily, whether in a notebook, a box, or a computer. At this stage, just collect whatever might be relevant without too much filtering or analysis. This is not as simple as it sounds. Sometimes people are too impatient, and they want to make great discoveries even when they do not know enough. Others might be unwilling to explore unfamiliar territory and so fail to gather the data they need.

2. Step 2 : Exploration

At some point, students need to stop collecting and start analyzing and digesting what they have collected. This might mean trying to classify the material, reorganize them, look at them from different perspectives, and trying to connect ideas and draw conclusions. The aim is to use the connections to come up with a new and useful idea. In the next chapter, they shall look at a list of thinking techniques that can help them accomplish this, but remember that this part of the creative process requires a lot of concentration, analysis, and patience. If possible, avoid all distractions and devote $100 \%$ of their attention to the task for a long period of time. A few things might then happen. First, they might get some preliminary ideas and conclusions about what might or might not work. So make sure that they always have a notebook ready in case you need to record your thoughts. Writing them down can make the ideas clearer, and we can build on them or revisit them later.

Second, they might discover gaps in the collected material. If so we need to fill in these gaps ourselves or collect some more data. Finally, it can get mentally exhausting trying to find order in chaos. But do not give up so soon even if you do not seem to be getting anywhere. Keep trying and come up with a few more observations. When they absolutely cannot continue, they have earned your well-deserved break.

3. Step 3 : Incubation

This is when they leave their task aside, relax, and forget about what they have been doing, and just wait. Many of us might have had the experience of being 
unable to solve a problem, but after a good night's sleep the solution came up suddenly the next morning. Or an idea might come to they while they are listening to music, taking a shower, or watching a movie. For some strange reason, a period of inactivity after intensive thinking does seem to promote creativity. The fact that sleep enhances creativity is well documented. Some people say it is because it gives a chance for the unconscious mind work on the problem. But maybe a period of timeout helps us look at the problem with a fresh eye. But whatever the explanation might be, working as hard as we can and then taking a break appears to be an effective strategy for most people. They need to find some activity (or inactivity) that stimulates their imagination most. Of course, there is no guarantee that taking a break will produce a creative idea inevitably. In that case, we need to go back to either step 1 or 2 and try again.

4. Step 4 : Verification

Once we have obtained some promising ideas, we should check whether they really work and whether they can be improved further. When we are dealing with a problem that requires a complex solution, it is very rare that the first solution we come up with is the perfect one. If the proposal turns out not to work, we should try to understand why, so that we can avoid similar mistakes in the future. Even when we have found the perfect solution, we can always review the whole creative process to see how we can repeat the success. Although we often read about the successes of creative people, we usually pay less attention to their failures. But many successful people are successful precisely because they are willing to take risks and fail, or they have failed spectacularly but have managed to learn from their failures and rise above them. What is important is that we know why we fail and learn from our mistakes.

Here are some main reasons why people fail in their creative endeavors:

1. Failure due to lack of knowledge: New ideas are based on past knowledge. Their idea might not be successful if they do not know enough, or they lack the relevant skills. Response: Learn more.

2. Failure of concept: This means there is something fundamentally wrong with the initial idea or theory. Whether in science or in art, creativity always contains an element of luck. Sometimes we discover that our favorite approach turns out to be a dead end, but only after considerable time and resources have been spent. Response: Tough luck. Ditch the approach decisively and quickly, and move on to something else. 
3. Failure of judgment: They can have the right idea, but make the wrong decision in executing and developing it. Maybe they were careless about the details. Maybe they did not work fast enough and other people beat they to it. Again they might also just be unlucky and made the wrong call. Response: Reflect and improve their work process, especially if they have failed the same way before.

4. Failure of attitude: Forging a new path where others have not gone before requires courage and the right balance of attitude. Fear of failure causes us to abandon an idea before it comes to fruition. Complacency makes us think we can get away with mediocrity without significant sacrifice.

\section{B. Inquiry Model}

Kilbane \& Milman (2014: 250) "inquiry has a variety of positive outcomes and student learning in science, such as improvement in science literacy, familiarity with science processes, vocabulary knowledge, conceptual understanding, critical thinking, and positive attitudes toward science". Inquiry produces positive results and learners learn in science, such as increasing scientific literacy, familiar with the process of science, vocabulary knowledge, understanding concepts, critical thinking, and positive attitudes toward science. The same thing was also expressed by Majid (2014: 173-174).

Inquiry learning is a series of learning activities that emphasize critical and analytical thinking processes so that inquiry can develop the ability to think systematically, logically, and critically. Learners are encouraged to look for and find their own answers to a question in question. The habit of inquiry models can improve students' scientific attitudes, but male students and women have no difference.

In inquiry-based science education, children become engaged in many of the activities and thinking processes that scientists use to produce new knowledge. Science educators encourage teachers to replace traditional teacher-centered instructional practices, such as emphasis on textbooks, lectures, and scientific facts, with inquiry-oriented approaches that (a) engage student interest in science, (b) provide opportunities for students to use a ppropriate laboratory techniques to collect evidence, (c) require students to solve problems using logic and evidence, (d) encourage students to conduct further study to develop more elaborate 
explanations, and (e) emphasize the importance of writing scientific explanations on the basis of evidence (Secker in Abdi, 2014).

"Male and female students had no significant difference in respect of their scientific attitude" (Pillai, 2012: 36). Based on various explanations of the guided inquiry model, inquiry can be formulated as a process carried out by the teacher to identify problems and provide many incentives for students to find problems and find alternative solutions to problems through scientific processes and supported using critical and logical thinking. The scientific process here does not have to be in the form of laboratory activities but can be sought from various learning sources.

Content Standard for Science as Inquiry: Fundamental Abilities Necessary to Do Scientific Inquiry (Olson \& Horsley, 2000: 17)

Grades K-4 (1) Ask a question about objects, organisms, and events in the environment; (2) Plan and conduct a simple investigation; (3) Employ simple equipment and tools to gather data and extend the senses; (4) Use data to construct a reasonable explanation; and (5) Communicate investigations and explanations.

Grades 5-8 (1) Identify questions that can be answered through scientific investigations; (2) Design and conduct a scientific investigation; (3) Use appropriate tools and techniques to gather, analyze, and interpret data; (4) Develop descriptions, explanations, predictions, and models using evidence; (5) Think critically and logically to make the relationships between evidence and explanations; (6) Recognize and analyze alternative explanations and predictions; (7) Communicate scientific procedures and explanations; and (8) Use mathematics in all aspects of scientific inquiry.

Content Standard for Science as Inquiry: Fundamental Understandings About Scientific Inquiry (Olson \& Horsley, 2000: 20)

Grades K-4 (1) Scientific investigations involve asking and answering a question and comparing the answer with what scientists already know about the world; (2) Scientists use different kinds of investigations depending on the questions they are trying to answer; (3) Simple instruments, such as magnifiers, thermometers, and rulers, provide more information than scientists obtain using only their senses; (4) Scientists develop explanations using observations (evidence) and what they already know about the world (scientific knowledge); (5) Scientists make the results of their investigations public; they describe the investigations in ways that enable others to repeat the investigations; and (6) Scientists review and ask questions about the results of other scientists' work. 
Grades 5-8 (1) Different kinds of questions suggest different kinds of scientific investigations; (2) Current scientific knowledge and understanding guide scientific investigations; (3) Mathematics is important in all aspects of scientific inquiry; (4) Technology used to gather data enhances accuracy and allows scientists to analyze and quantify results of investigations; (5) Scientific explanations emphasize evidence, have logically consistent arguments, and use scientific principles, models, and theories; (6) Science advances through legitimate skepticism; and (7) Scientific investigations sometimes result in new ideas and phenomena for study, generate new methods or procedures for an investigation, or develop new technologies to improve the collection of data.

Based on several sources the inquiry model syntax are (1) ask a question or making formulation of the problem; (2) plan and conduct a simple investigation or making temporary answer; (3) gather data and extend the senses; (4) use data to construct a reasonable explanation or analyzing; and (5) communicate investigations and explanations.

Structured inquiry model is a model that promotes the involvement of learners actively and creatively in the search for, examine, formulate concepts and principles of geometry and to encourage students to develop intellectually and skill in solving the problem. In the structured inquiry model student-centered learning, so that students can actively participating in the learning process. According to Sanjaya (2009), the main objective of the strategy is the development of inquiry structured thinking skills-oriented learning process. Criteria for success of the learning process by using the inquiry model structure is not determined by the understanding of the learning material but the extent to which students are active search for and find something. Structured inquiry model emphasizes on the development of cognitive, affective and psychomotor balanced manner so that through this model of learning more meaningful.

In relation to learning goemetry, students are directed to formulate a hypothesis, perform experiments related to the learning material geometry and make conclusions to answer the hypothesis. In studying and developing the science needs to be supported by students' attitudes in students. Student attitudes related to skill groups in the field of the requirements for the learning process. So in essence the attitude of students is a tendency or impulse to behave and thinking in accordance with the model expected. 
The attitude of students consists of curiosity (curiosity), flexibility (flexibility), critical reflection (critical student attitudes), and honest. Students who have high student attitudes will have fluency in thinking that they will be motivated to excel and have a strong commitment to achieve success in learning. In studying the geometry of the learning material presented by the use of structured inquiry model, students' attitudes are very influential in the learning process. Frequent case is the lack of a critical attitude and less eager students in learning mathematics, students' attitudes like this are not expected to arise in the implementation of learning in the classroom or laboratory. Thus, in the present study attitudes students need to be a review (Salim \& Tiawa, 2015).

\section{RESULT AND DISCUSSION}

Process standard (Mendikbud, 2016: 3) say that "to strengthen the approach integrated scientific (thematic), thematic subjects, and thematic (in a subject) needs to be applied based learning disclosure / research (discovery / inquiry learning)". It means that learning in this curricula suggest to learning with activities. The inquiry models procedure are observing, asking question, gathering information, analysing, and communicating. Those activites can develop the thing skills ability of students.

Table 1. The Inquiry Model Syntax Relationship with Indicator Creative skills

\begin{tabular}{llll}
\hline $\mathbf{N o}$ & The Inquiry syntax & $\begin{array}{c}\text { (to develop) } \\
\text { skills }\end{array}$ & Indicator \\
& & Creative \\
\hline $\mathbf{1}$ & making formulation of the problem & Preparation \\
\hline $\mathbf{2}$ & making temporary answer & Preparation \\
& & Incubation \\
\hline $\mathbf{3}$ & gathering data & Preparation \\
\hline $\mathbf{4}$ & use data to construct a & reasonable & Verification \\
& explanation & Exploration \\
\hline $\mathbf{5}$ & Communicate & Exploration \\
\hline
\end{tabular}

Students thinking skills and problem solving skills refers to the ability of students to generate ideas related to tasks given to them. This table tells that inquiry activities can nurturing the creative skills students. Making formulation of the problem 
can develop the preparation step. Making temporary answer can suggest the Preparation and Incubation steps. Gathering data can increasing Preparation step. Use data to construct a reasonable explanation can develop Verification and Exploration steps. Then communicate can nurturing Exploration step.

The relevant research is described on Creative Flood Games. Students used creativity skills to put recycled and found materials to new uses or to use parodies of existing games in their flood games. Flood game products were of several types: fine motor skill activities, a word find, board games, a flood simulation game, a memory game, and matching puzzle games. The fine motor skill games were made by younger students and involved using tongs to move animals or people from flooded areas to safety or to place miniature sandbags along a river to build a flood levee.

A fine motor skills game was made a student who was very concerned about the animals that would become engulfed in flood waters. (1) She found clipart images of her favorite animals, mirrored them on the computer, and cut them out. She glued a pompom in between the two sides to make them three-dimensional, so they could stand and be easily manipulated using tongs. (2) a village fashioned from cut pieces of craft foam, trees represented by green flat glass marbles, and hills made of trimmed foam packing material, and the river represented by shredded blue paper. (3) a player draws a card from a stack of 20 scenarios and reads the information, such as, "Floodwater fills home-people need rescue," "Live power lines down—rescue people," or "Man drives car through flooded streets; car floats away-rescue people," and then acts out the drama by picking up plastic people with tongs and placing them on the rooftop for helicopter or boat rescue. Blue shredded paper was used to represent the flood waters, while brown rocks represented boulders and debris carried by the flood waters. Students made the homes out of used paper cartons with clip art house fronts glued to them, and so on.

Finally, the project asked students to create an authentic product-a flood game- that would allow them to practice creative thinking and invention while applying recently-learned information about floods. Students were thoroughly engrossed in developing their flood games and finding interesting facts for game questions. They worked individually or in small groups to create an authentic product-a flood gameusing recycled or found materials such as pebbles, sponges, cardboard, plastic lids, fabric scraps, string, clothespins, and egg or milk cartons. This allowed them to assign new uses to common materials, thereby practicing creativity and their newly-acquired knowledge of floods. A focus on the current, local science issue of floods with an 
authentic product motivated the students. Incorporation of thinking skills boosted effective processing of information, while attention to the science domain of creativity resulted in exciting game products. This enrichment unit on flooding exemplifies a successful, challenging, integrated, authentic science project (Rule, et al, 2012).

Some teachers commented that they are too busy and find it difficult to infuse thinking skills and problem solving skills in their classroom lessons. It is important for the teachers to be competent at various skills to help pupils in their thinking skills and problem solving skills. The ministry of education should conduct courses for the in service teachers on ways to infuse thinking skills among pupils of different abilities. This is important, so that teachers do not neglect the weaker pupils and only concentrate on the good ones while teaching. The finding from the focus group interviews also show that teachers should use different kinds of material to accommodate the diversity of the pupils, such as using different worksheets for pupils of different levels (Nair \& Ngang, 2012).

At the preparation stage, usually creative thinkers gather information and test it by using many thought processes. At the incubation stage they usually use their time by imagining it unconsciously. at the illumination stage, ideas or ideas are sought. the last stage is verification, where students try to verify and try out the ideas they bring up. Creative students are substantially able to overcome difficulties and tasks that are open ended.

The use of inquiry models in implementing classroom learning is one of the efforts to develop students 'abilities with the aim of increasing cognitive abilities but also students' creative thinking abilities. The ability to think of helping students in longterm education is not only about academic ability but also to help students face a more real life.

inquiry model is divided into 3. one of which is a guided inquiry model, this model is the most appropriate for primary school children. because at this stage the children are guided to carry out procedural activities in accordance with the syntax of the inquiry. habituation to guided inquiry learning can develop the scientific attitude of students to get used to working procedurally and solving problems creatively. improve creative thinking and create new innovations. 


\section{CONCLUSION}

Inquiry model to improve creative thinking ability can be achieved when all learning syntax is fulfilled. creative process requires a lot of concentration, analysis, and patience. Inquiry learning is a series of learning activities that emphasize critical and analytical thinking processes so that inquiry can develop the ability to think systematically, logically, and critically which is a characteristic of creative thinking. Learners are encouraged to look for and find their own answers to a question in question.

Inquiry-based research (inquiry) is a research that requires students to prove a fact. This requires students to be diligent for the success of the experiment because otherwise it is not proven and unsuccessful. Therefore repetition is needed to be achieved. This activity can increase students' perseverance. In the final guided syntax that is making conclusions based on the facts encountered, can improve the scientific attitude of discovery and creativity. The inquiry model is model that based on discovery then it can nurturing the creatifity os students. The elementary students can do it with the simple method and they can conduct it with the various games to solves their problem.

\section{REFERENCES}

Abdi, Ali. (2014). The Effect of Inquiry based Learning Method on Students' Academic Achievement in Science Course. Universal Journal of Educational Research 2(1): 37-41.

Depdiknas. (2003). Undng-Undang RI Nomor 20, Tabun 2003, tentang Sistem Pendidikan Nasional. Jakarta: Depdiknas.

Lau, Joe Y. F. (2011). An Introduction To Critical Thinking And Creativity. ISBN 9780-470-19509-3. New Jersey : John Wiley \& Sons, Inc., Hoboken.

Jones, Russel \& Dominic., Wyse. (2013) Creativity in the primary Curriculum Second edition.USA : Routledge

Kind,P.M \& Kind, V. (2007). Creativity in Science Education : Perspective and challenges for Developing School Science. Studies In science Education, 43,1-37.

Kilbane, C. R.\& Milman, N. B. (2014). Teaching models designing instruction for $21^{\text {st }}$ century learners. USA: Pearson.

Majid, A. (2014). Pembelajaran tematik terpadu. Bandung: PT Remaja Rosdakarya. 
Mendikbud. (2016). Peraturan Menteri Pendidikan dan Kebudayaan Nomor 22, tabun 2016, tentang Standar Proses.

Nair \& Ngang. (2012). Exploring Parents' and Teachers' Views of Primary Pupils' Thinking Skills and Problem Solving Skills. Creative Education Journal Vol.3, No.1, 30-36.

Olson, Steve \& Horsley, Susan Loucks. (2000). Inquiry and the National Science Education Standards: A Guide for Teaching and Learning. ISBN: 0-309-518954, 224 pages. This PDF is available from the National Academies Press at: http://www.nap.edu/catalog/9596.html

Pillai, K. (2012). An analytical study on scientific attitude of higher secondary school students in virudhunagar district. International Journal of Teacher Educational Research (IJTER) Vol.1 No.4, 32-37.

P21 Headquarters. (2007). Creativity and Innovation. Taken from http://www.p21.org/about-us/p21-framework/262-creativity-and-innovation at Thursday, November $23^{\text {rd }} 2018$.

Rule, Audrey C. Et al. (2012). Creativity and Thinking Skills Integrated into a Science Enrichment Unit on Flooding. Creative Education Journal Vol.3, No.8, 1371-1379.

Salim, Kalbin \& Tiawa, Dayang Hjh. (2015). Implementation of Structured Inquiry Based Model Learning Toward Students' Understanding of Geometry. International Journal of Research in Education and Science Volume 1, Issue 1, Winter ISSN: 2148-9955 